\title{
Video-arte de Guillermo Cifuentes: El lenguaje del desarraigo
}

\section{Guillermo Cifuentes' Video-Art: Language of Rootlessness}

\author{
Romina Arata De Nordenflycht \\ Natalia Cabrera Figueroa \\ Catalina Donoso Knaudt \\ Universidad de Chile \\ romina.arata@gmail.com
}

\begin{abstract}
Resumen
Llegado el período de transición a la democracia en Chile, las cámaras de video, antes utilizadas por artistas plásticos en su búsqueda de denuncia política y social, son ahora tomadas por una nueva generación de creadores, en su mayoría audiovisualistas de formación universitaria. Influenciados por tendencias conceptualistas, ellos desarrollan una retórica en común que los diferencia de los anteriores por experimentar con las posibilidades técnicas que este formato les puede proporcionar.

De esta generación surge Guillermo Cifuentes como una figura algo difusa dentro del medio, pues muere repentinamente el año 2007 y sus obras quedan dispersas y sin acceso para el público general. Dado esto, la presente investigación tuvo por objetivo catastrar sus obras de video-arte e identificar en ellas sus rasgos característicos. El propósito es, dado que desarrolló un lenguaje particular, establecerlo y definirlo como un autor relevante dentro del video-arte chileno.
\end{abstract}

Palabras clave: Guillermo Cifuentes, video arte, video experimental, Chile

\begin{abstract}
In Chilean transition to democracy, video cameras, formerly used by artists in their quest for social and political denunciation, have been taken by a new generation of audiovisual artists, mostly trained in colleges. Influenced by conceptualist trends, they develop a common rhetoric, different from previous generation because of their experimentation of technical possibilities that this format can provide.

Within this generation Guillermo Cifuentes appears as a somewhat diffuse figure, who suddenly died in 2007, not well known by public audience. This paper aims to list Cifuentes' works in video format and identify its characteristic features. W estate that, as he developed a particular language, he is an important author in Chilean art video.
\end{abstract}

Keywords: Guillermo Cifuentes, video art, experimental video, Chile 


\section{Introducción}

En el año 2007 el artista Guillermo Cifuentes fallece repentinamente en un accidente de transito. Con tal solo treinta y nueve años logró realizar numerosas y multidisciplinarias obras, destacándose especialmente con sus video-instalaciones y sus obras de video-arte. Su videografía, a pesar de haber sido reconocida dentro del medio, permanece dispersa y sin acceso al público general, lo cual posibilita que caiga en el olvido. Prevenir ese riesgo es lo que motiva este análisis, rescatando la herencia cultural que dicha obra significa. Por ello que un objetivo crucial para esta investigación ha sido el de hacer un catastro de su obra, en este caso específicamente aquella considerada video-arte según define el marco teórico. Las obras catastradas y analizadas han sido trece: Postal de lejos (1991), Beuys vive (1992), Release (1996), Ofrenda (1996), Have you ever imagine the future would look like this? (1996), Naturaleza muerta (1996), Sueños de ciego (1997), El equívoco (1997), la trilogía Lecciones nocturnas (compuesta por Comunión, Primera lección y Un puente que cae, 1997-1998), Three cornes: study for a circle 1 (2004) y Three cornes: study for a circle 2(2004).

Figura 1. Guillermo Cifuentes en su video Postal de lejos (1991)

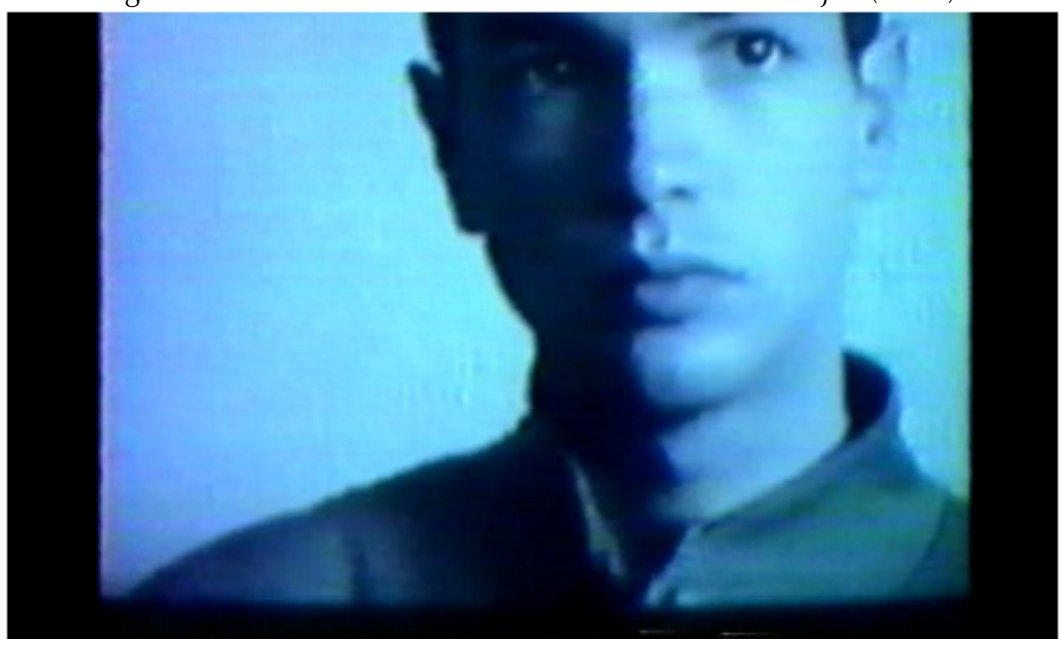

Luego, este análisis parte con el objetivo general de identificar los rasgos característicos de la obra de Guillermo Cifuentes, en pos de instaurar su figura como autoral dentro del video-arte chileno, es decir, como creadora de un lenguaje propio. Siguiendo esto, la hipótesis que se ha aventurado es que Guillermo Cifuentes, junto a otros artistas de su generación, instaura en Chile la utilización del video como medio de expresión artístico, a través de una obra que problematiza tanto el estatuto de este nuevo medio como el lenguaje que es capaz de crear.

Para acercarse al objetivo general e hipótesis señaladas, esta investigación se propuso objetivos específicos orientados a estudiar el contexto de su creación, lo que resulta imprescindible para comprender la obra del artista. Estos son: 1) realizar un catastro de su obra, 2) construir el concepto de video-arte, 3) estudiar el conceptualismo como vanguardia artística 
en relación a determinados discursos y estéticas que aporta al desarrollo del video-arte, 4) describir el escenario histórico del video-arte en Chile y, por último, 5) interpretar detalladamente la obra de Guillermo Cifuentes en relación a subiografía, su contexto histórico y a textos escritos de su autoría. Cabe destacar la escasez de textos referidos a la obra de Guillermo Cifuentes previo a esta investigación, por lo que sus propios escritos resultan fundamentales para acercarse teóricamente a su trabajo.

Para abordar todo lo anterior, la metodología utilizada ha abarcado tres ejes principales. En primer lugar, una exhaustiva revisión bibliográfica que sostenga al marco teórico, enfocado éste en comprender el concepto de video-arte. En segundo lugar, la realización de entrevistas a dos focos de interés: por un lado, a teóricos de arte y del medio audiovisual que ayuden a construir el marco teórico y ahonden en la obra de Guillermo Cifuentes; y por otro, a sus familiares y amigos, en pos de conocer su biografía. En tercer lugar, un visionado de obras de video-arte internacional que se sabe influyeron en su creación, como también de obras de video-arte nacionales, hechas por artistas de su generación y de años anteriores. Elvisionado de la obra de video-arte del propio Cifuentes fue de carácter mucho más analítico (se ha realizado con la ayuda de una ficha), debido a la importancia que adquiere para el objetivo de esta investigación, en especial en su última fase, la de la construcción del presente artículo.

A continuación se propone indagar en los temas considerados pertinentes para acercase a la obra de Guillermo Cifuentes. Así se estudia el concepto de video-arte a partir de tendencias artísticas experimentales que influyen en su desarrollo, para luego explorar dicho concepto en el ámbito nacional. Por otro lado, también se indaga brevemente en la biografía del autor mencionado.

\section{Video-arte: un cruce de experimentaciones artísticas en el mundo y en Chile}

En 1965 Sony lanza al mercado la primera cámara de video portátil: Portapack. Esta nueva tecnología, a diferencia de la cámara de cine, graba y almacena la información simultáneamente en una cinta electromagnética, presentándose así con una rudimentaria notablemente más simple en términos prácticos.

Lo anterior ocurre en un contexto en que los medios de comunicación y la alta cultura han ido instaurando en la sociedad, cada vez más, sus reglas de entendimiento oficiales para construir un verosímil hegemónico. Según la escritora Nelly Richard, ello ha sido posible a través de ciertos efectos de representación que naturalizan lo realmediante a una relación fija e inamovible entre significantes y significados. Ante esta situación el arte ha respondido con el surgimiento de nuevas manifestaciones, las cuales apuntan hacia la reflexión acerca de su posición dentro de dicho contexto, es decir su posición dentro de una institucionalidad validada para valorizar qué es arte y que no (las historias del arte, las galerías, los museos). Elarte es lo que nombramos arte, declara el artista plástico Marcel Duchamp en 1917.

Cabe destacar a este último artista en tanto ser relacionado frecuentemente con el conceptualismo, una de estas nuevas manifestaciones artísticas, que, según el crítico de arte 
Carlos Ossa, de manera esencial se constituye como una crítica y reflexión semiológica hacia su contexto. Para el crítico, dicha motivación es lo que define al conceptualismo como una manifestación estrictamente política;

En definitiva, entonces la idea de complot vanguardista como una política que parte de la hipótesis de que el valor no es un elemento interno, inmanente, sino que hay una serie de tramas sociales previas sobre las cuales el artista también debe intervenir. Y que esas tramas definen lo artístico. Son lo artístico. Por eso, a menudo, la práctica de la vanguardia consiste en construir la mirada artística y no la obra artística. (Ossa, 2005: 163)

Figura 2. Buda (1974) de Nam June Paik

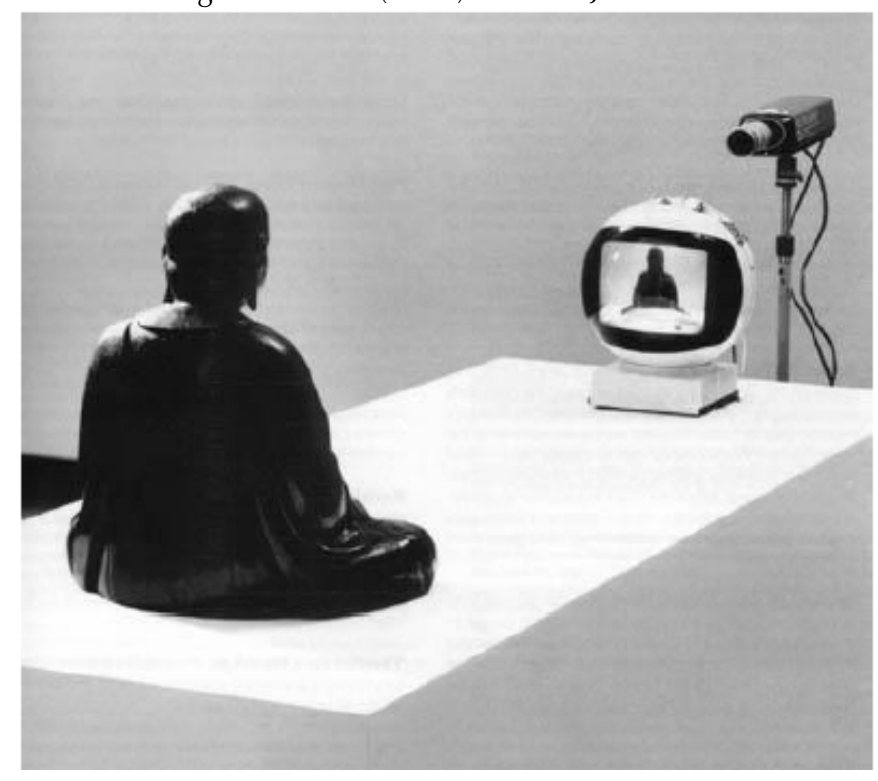

Bajo la influencia del conceptualismo y por su mayor accesibilidad, el video comienza su desarrollo como lenguaje abriendo camino hacia la reflexión y la experimentación por parte de variados artistas. Nam June Paik, sur-coreano denominado El padre del video-arte y perteneciente al movimiento conceptualista Fluxus, presenta a sus amigos en 1965, en el café Au Go Go de Nueva York, el registro en video que muestra el tumulto callejero que surge durante la visita del Papa Paulo VI. Lo novedoso de este hecho es el aprovechar las características del formato video: el fácil acceso a imágenes grabadas ese mismo día y que además, se concentraban en mostrar a las personas y sus reacciones ante la presencia del Papa, provocando discusión acerca de las mismas. Este evento abre camino a este soporte como un espacio de reflexión audiovisual, característica de futuras generaciones que seguirán este rumbo.

Nam June Paik conoce en estos encuentros a artistas internacionales con quienes dialoga y trabaja hasta su muerte en el año 2006; Bill Viola, John Cage y Andy Warhol, entre varios 
destacados. Nam June Paik se destaca por hacer visible las posibilidades de experimentación de esta nueva tecnología, en cuanto permiten producir un circuito cerrado, es decir la simultaneidad de tiempo real de registro y de reproducción, el en vivo como se conoce actualmente. En su afán conceptualista, dichas posibilidades las orienta hacia la realización de una crítica a la televisión como medio de comunicación que en aquel tiempo está instaurando suhegemonía.

Paralelamente, otros artistas utilizan el video para registrarse a sí mismos u a otros haciendo acciones de arte, lo cual hace surgir una creación de obras con cruces interdisciplinarios que con el tiempo se van constituyendo como nuevos lenguajes, tales como las Perfomances o los Happenings. Wolf Vostell, perteneciente también a Fluxus, crea diferentes tipos de eventos en donde los participantes viven una experiencia real de una situación artística, la cual es registrada en video. Por ello es que según la artista y escritora Catherine Elwes, lo que caracteriza a la Performance es la relación de igualdad que se da entre el arte y la vida. Luego con artistas como Vito Acconci, Joan Jonas y Peter Campus en Estados Unidos, las Performances comienzan a tener pretensiones más propiamente artísticas debido a que su realización es configurada por la presencia de la cámara, con la cual busca interactuar más firmemente. Muchas veces ello se realiza a través del circuito cerrado.

Se puede decir que las influencias conceptualistas que rodean al uso del video ya antes habían repercudido en el cine experimental, según como afirma el teórico de cine y video A.L. Rees. Un nombre importante al respecto es el movimiento New American Cinema, surgido a fines de la década de los cincuenta, por el gesto que realiza un grupo de artistas de alejarse del ilusionismo promovido por Hollywood, buscando explorar de forma libre las posibilidades que les brinda el lenguaje cinematográfico. De este movimiento cabe señalar a Maya Deren quien propone la idea de un cine anarrativo al introducir el concepto de la poesía en el cine. Poesía ligada a la producción de imágenes referidas más a ritmos, simbolismos y sensaciones que a una narración aristotélica lineal y explícita. Por su parte, Stan Brackhage realiza una obra motivada por proponer una forma de ver, la cual está ligada íntimamente a la reflexión sobre la materialidad del soporte, el cual raya e interviene. Para el teórico de cine Udo Jacobsen dicho fenómeno da cuenta del lenguaje cinematográfico como un campo de problemas, más que de soluciones, con respecto a las capacidades técnicas del formato. Característica que comparte con el video en tanto manifestación artística; "El video-arte le debe harto al cine experimental, yo lo considero fundamentalmente una proyección en otro formato del cine experimental". ${ }^{1}$

Pero precisamente esta motivación que guardan en común el cine y el video-arte los hace divergir por caminos separados, pues las características de su soporte son diferentes en ambos. Cabe entonces preguntarse: ¿Qué caracteriza al video-arte?

El teórico y realizador de video-arte Néstor Olhagaray señala que, al contrario de la imagen cinematográfica, cuyo soporte (el celuloide) captura la imagen del referente de forma fidedigna, los parámetros técnicos del video posibilitan la reproducción de una imagen menos fiel al referente, produciendo que ésta adquiera una materialidad que se puede acercar más a la

${ }^{1}$ Entrevista a Udo Jacobsen (01 de octubre 2009) por Romina Arata, Santiago de Chile. 
abstracción y que por ello se puede trabajar más conceptual y subjetivamente, “...incluso nos puede ayudar a describir o caracterizar realidades que son bastantes complejas y densas”.

Figura 3. Prelude 1 (1996), Stan brakhage, imágenes características de la intervención del artista sobre el celuloide.

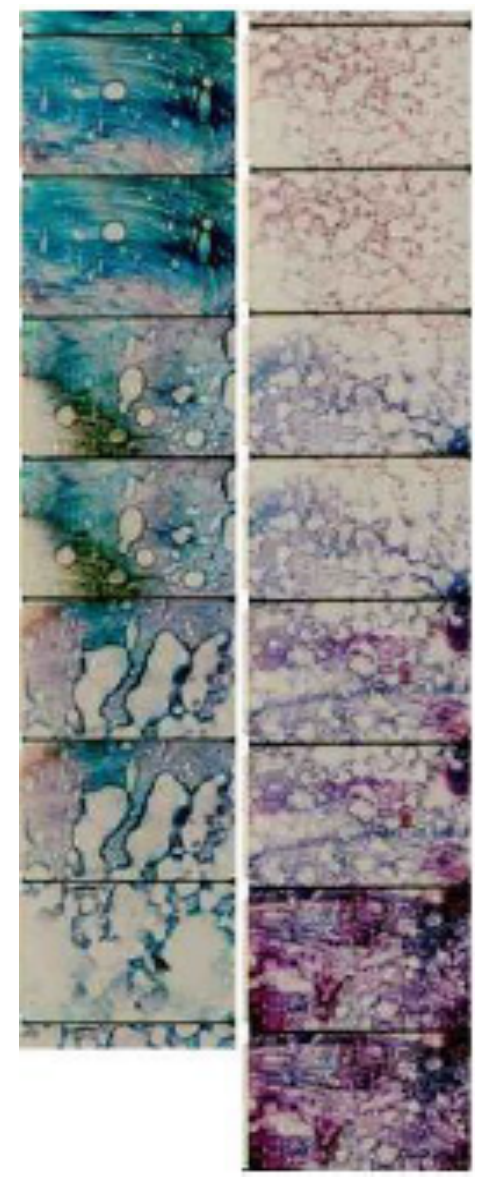

Además, el autor afirma que la imagen electrónica propia del video guarda una gran versatilidad y por tanto, mayores alternativas para experimentar con su plasticidad en el momento de postproducción, ya sea alterándola o modificando sus elementos. El video-arte entonces, se caracteriza por encontrar en su propio soporte una materialidad moldeable según el deseo creativo del artista, abriendo posibilidades de trabajar más bien conceptos que intentar la representación fiel de la realidad. Cabe destacar aquí además de Nam June Paik, a Steina y Woody Vasulka, Ed Emshwiller, Eric Siegel y Shuya Abe, quienes trabajan con sintetizadores capaces de transformar las imágenes mediante procesos electrónicos, configurando de esta

\footnotetext{
${ }^{2}$ Entrevista a Nestor Olhagaray, Santiago de Chile, 06 de octubre 2009.
} 
manera un lenguaje que utiliza la grabación más bien como un croquis para posteriormente trabajar todas sus posibilidades creativas en el momento de postproducción.

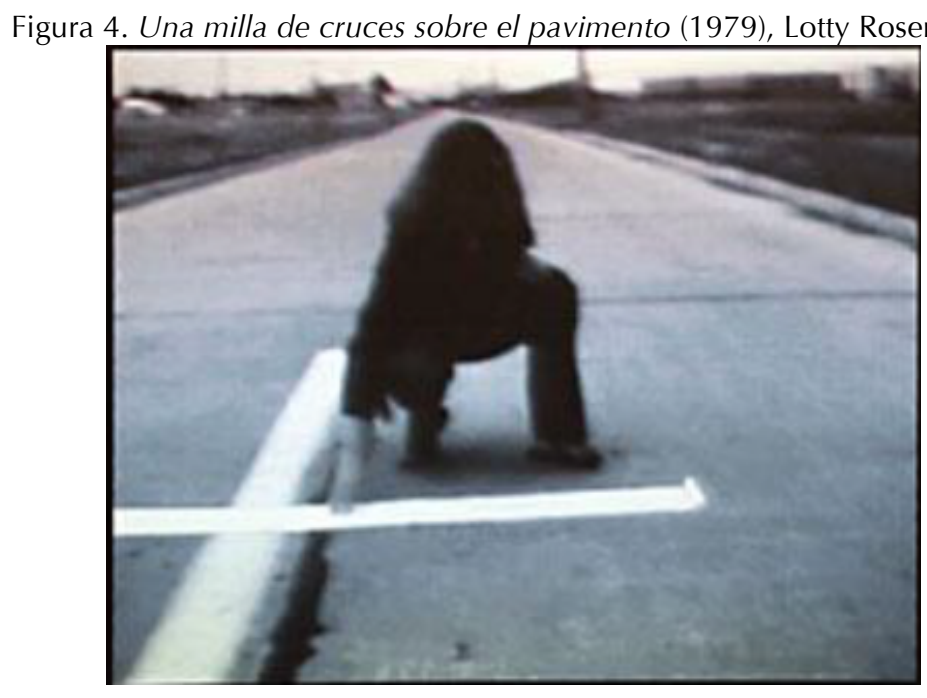

En Chile, los orígenes del video-arte se pueden encontrar a fines de la década de los setenta, contexto marcado por el régimen militar que gobierna en ese entonces y, así mismo, por la llegada de la tecnología del video al país. Ante la censura que produce este régimen hacia cualquier forma de expresión cultural, los artistas visuales Juan Castillo y Lotty Rosenfeld, el poeta Raúl Zurita, la escritora Diamela Eltit y el sociólogo Fernando Balcells, crean el Colectivo de Acciones de Arte (CADA). La primera acción realizada por el colectivo se titula "Para no Morir de Hambre en el Arte", de la cual, al igual que las posteriores acciones, parte importante de la misma se desarrolla en las calles de la ciudad. Ello como manera simbólica de transformar ésta última de tal manera que sea un espacio de expresión artística, facilitadora del encuentro entre el ciudadano común y el arte, un traslado del museo a la ciudad que ayude a generar un contradiscurso del régimen político imperante, que les imposibilita pensar la realidad de una forma que no esté bajo su ideología. Pero sobre todo la importancia de CADA recae en el utilizar el video como forma de registro de estas acciones, con la motivación de conservarlas en el recuerdo y difundirlas, así, la agrupación es la primera en Chile en utilizar el video en relación a su arte.

Es por esto último que para Carlos Ossa La Escena de Avanzada (corriente artística cuyo nombre crea Nelly Richard para definir el arte chileno de las últimas décadas, a la cual pertenece el CADA) como también el arte en general en el Latino-América de esos años, recoge influencias del conceptualismo europeo y norteamericano, pero en una motivación más antropológica que semiótica. Lo cual significa que las experimentaciones en el campo del lenguaje deben tener consecuencias políticas manifiestas, es decir deben ayudar a generar participación en la comunidad con el fin de volver a unirla, ante su desintegración dictatorial. "Entonces ya no se trata de trabajar con los elementos abstractos, con las teorías 
revolucionarias, se trata un poco de esta cosa tan enérgica, tan efervescente, tan, comillas, revolucionaria de volver todo a acción, de volver todo a una praxis". ${ }^{3}$ Caso similar al CADA (pero sin registro en video) que ejemplifica estas tendencias de arte-vida en Argentina es el que explica el historiador de arte Uruguayo Luis Camitzer con el caso de Tucumán Arde. Esta agrupación artística nace una década antes que el CADA y realiza Happenings en que encierran a los visitantes de galerías en las mismas, representando así una situación de captura, la cual acaba cuando ya llegan las autoridades. Su intención es hacer que los visitantes lleguen a vivir realmente el encarcelamiento y que luego quede para siempre en su memoria.

En Chile, desde el periodismo y el cine surgen en la década de los ochenta nombres como Juan Enrique Forch y Carlos Flores, y desde las artes plásticas, Eugenio Dittborn, Carlos Leppe y Carlos Altamirano. Estos autores, a diferencia del CADA, comienzan a trabajar con las posibilidades técnicas que les brinda el video, el la búsqueda de nuevos lenguajes. Eugenio Dittborn y Lotty Rosenfeld, por ejemplo, se dedican a experimentar con recursos cinematográficos como el montaje. Sin embargo, según Udo Jacobsen, en dicha época predomina el uso del video para el registro de performances (al estilo Fluxus), como las que realizan Carlos Leppe y Carlos Altamirano.

Para estos realizadores, acercarse a este formato es una tarea difícil, pues la mayoría de las veces carecen de equipos propios, recurriendo a préstamos y al intercambio de obras como forma de retribución. De esa precariedad de medios técnicos sólo escapan dos chilenos de especial importancia para el video-arte nacional e internacional: Alfredo Jaar y Juan Downey, éste último, considerado El padre del video-arte en el mundo. Downey, proveniente de la pintura, el dibujo y el grabado, viaja en los años sesenta a Europa y luego a Estados Unidos, donde se establece y descubre el video. Sus experimentaciones derivan en una obra de alta calidad y repercusión a gran escala, más en el extranjero que en Chile.

A principios de los ochenta la práctica del video se había ampliado de tal forma, que se organiza el Primer Encuentro de Video-Arte Franco-Chileno, organizado por el Instituto Chileno-Francés de Cultura. Fue resultado de la iniciativa de Jean Michel Solonte, en esa época Jefe del Servicio de Extensión Cultural de la Embajada de Francia en Chile. Dicho encuentro posibilita por primera vez el visionado público tanto de obras francesas como chilenas, además del intercambio cultural entre dichos países (esto último especialmente a través del premio que recibían los realizadores ganadores, que consistía en hacer un "diario de viaje" en Francia). Con el paso de los años, se observará una crisis dentro del evento (lo que no motiva su desaparición), pues se presentan obras con discursos y estéticas muy disímiles, muchas de ellas con fines netamente contestatarios. Ello implica la dificultad de definir criterios evaluativos para los curadores y el enfrentamiento entre realizadores. Cabe mencionar que por esos años se crea otra plataforma de difusión para el video-arte: el programa televisivo En torno al video, el cual, bajo la conducción y guión de Carlos Flores y la dirección de Carlos Godoy, realiza en el Canal 4 de la Universidad Católica de Valparaíso un ciclo de ocho programas durante tres años consecutivos.

${ }^{3}$ Entrevista a Carlos Ossa, Santiago de Chile, 25 de septiembre 2009. 
Figura 5. Through the looking glass (1982), Juan Downey

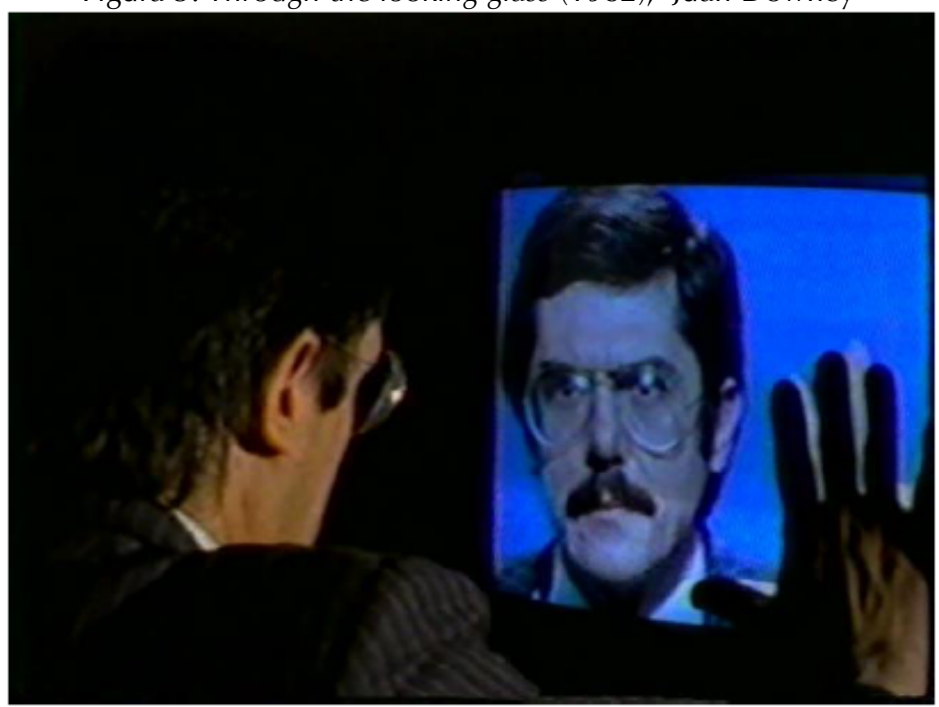

En los noventa, con el retorno de la democracia y el fin de la represión directa del régimen militar, se vuelven a abrir espacios de expresión cultural. Bajo esta nueva situación el video, con su corta trayectoria, queda de lado frente a las instituciones del cine y la televisión, ya constituidas, y ahora abiertas al diálogo que antes solo permitía el video. Ello implicó en principio una merma en la creación de video-arte y un estancamiento en la producción a nivel general, lo que sumado al desligamiento de la administración francesa de la organización de los Encuentros de Video-Arte Franco-Chilenos, producen una nebulosa en este terreno.

Buscando revertir lo anterior es que en 1992 se crean los Encuentros de Video-Arte FrancoLatinoamericanos, realizados en forma paralela (desde 1993) a las Bienales de Video y Artes Electrónicas (llamada actualmente Bienal de Video y Nuevos Medios). Vale destacar que estas últimas siguen vigentes hasta el día de hoy, bajo el amparo constante de su precursor, Néstor Olhagaray.

Estos nuevos Encuentros guardan gran importancia, ya que ganan reconocimiento internacional al ser la primera instancia en reunir trabajos más complejos e íntegros que, con una labor de montaje nueva y renovada, experimentan con las posibilidades que les brinda la materialidad del soporte. Las nuevas tendencias que se observan en estas obras se basan en ideas conceptualistas, ya no de origen antropológico, sino más bien por cómo se origina esta tendencia en Europa y Norteamérica. Para Carlos Ossa ello permite la creación de discursos sumamente desconstruidos y fragmentados, puesto que trabajan con las fallas y los accidentes de la representación características del formato video, generalmente tomando temas personales e introspectivos, especialmente dirigidos a una reflexión sobre la memoria tanto individual como colectiva. Existe la necesidad de reconstruir la historia censurada por la dictadura, no con la esperanza de volver a unir a la comunidad, sino quedándose en el espesor 
de su disolución. Así lo hace esta nueva corriente de La escena de Avanzada, con nombres provenientes del área audiovisual como Germán Bobe, Claudia Aravena, Gonzalo Ravanal y Guillermo Cifuentes.

\section{Guillermo Cifuentes: hijo del exilio}

Guillermo Cifuentes nace el año 1968 en Santiago de Chile. Debido al golpe militar de 1973 sus padres son exiliados del país y se muda a Noruega junto a ellos y a su hermana menor Antonia. La familia pasa ahí cuatro años bastante difíciles, por lo que Cifuentes se ve obligado a tomar responsabilidades mayores. Recuerda su hermana: “... mi hermano me alfabetizó, me cuidó en las tardes, o sea, en Noruega la vida era... nosotros vivíamos solos, o sea, pasábamos solos todo el día”. ${ }^{4}$

Además de ello, el clima y la forma de ser de las personas en Noruega, tan distinta a la chilena, hizo que sus padres se volvieran "prácticamente locos y dijeron: no vamos a pasar un año más en este lugar” (ibid.). Así la familia intenta vivir un tiempo en Alemania, en casas de amistades también exiliadas, pero esto dura pocos meses ya que luego se mudan nuevamente, esta veza Ecuador, lugar donde Cifuentes desarrolla su formación escolar.

Figura 6. Postal de lejos (1991), Guillermo Cifuentes.

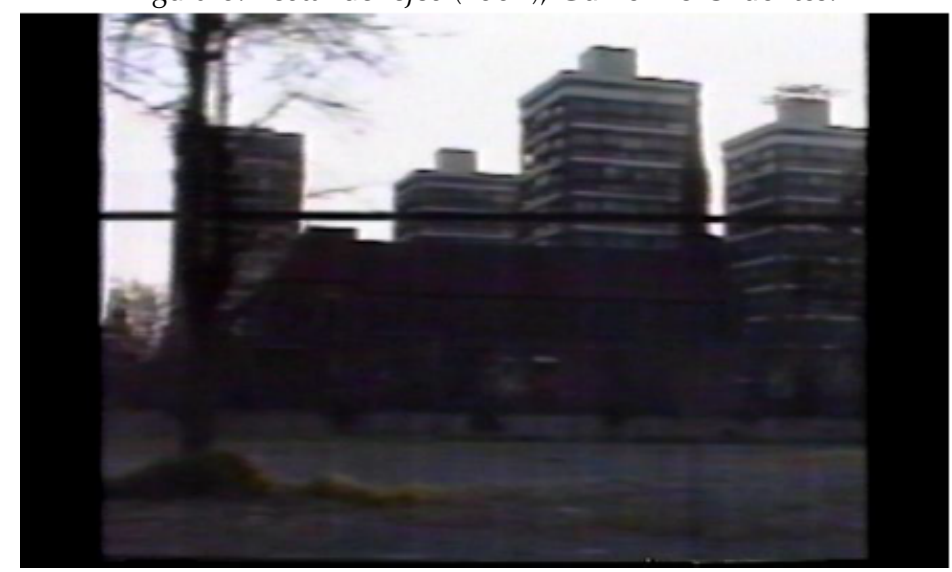

Al cumplir los veintiún años suceden dos eventos importantes en su vida: fallece su padre a la vez que en Chile se termina la dictadura. Cifuentes decide entonces comenzar sus estudios superiores en su país de origen y entra en el Instituto ARCOS a la Carrera de Comunicación Audiovisual. Es ahí donde conoce a Claudia Aravena, amiga con quien luego comparte reflexiones y proyectos audiovisuales. Cabe destacar que la formación que obtuvo en la escuela no necesariamente lo ubica dentro delámbito artístico. Aravena comenta:

\footnotetext{
${ }^{4}$ Entrevista a Antonia Cifuentes, (25 de septiembre 2009) por Catalina Donoso, Santiago de Chile.
} 
... nosotros, a pesar de actuar dentro del campo de las artes visuales, nosotros no venimos de esa reflexión pictórica como los que vienen de las bellas artes, sino de la semiología, del análisis de la imagen, esa fue nuestra formación, eso fue un poco lo que nos convocó y lo que nos marcó, para así decir, para siempre. ${ }^{5}$

Pues al terminar sus estudios superiores, Cifuentes y muchos de sus compañeros, de los que además de Claudia Aravena, cabe nombrar a Alejandra Egaña y a Patricio Pereira, comienzan a desarrollarse dentro del ámbito del video y de las posibilidades experimentales que éste brinda. Ello bajo la importante influencia de Néstor Olhagaray, a quien Cifuentes ayuda en la producción de las Bienales de Video y Artes Electrónicas.

Pero para subsistir económicamente, Cifuentes trabaja como montajista de documentales además de dedicarse a la docencia de montaje en el Instituto ARCOS. Cabe destacar que más adelante, en el 2004, obtiene un premio por el Mejor Montaje Documental en el Festival de Documentales de Valparaíso por su trabajo en Malditos: la historia de los Fiskales ad-hok.

A mediados del noventa gana premios en las tres primeras versiones del Festival Internacional de Cortometrajes de Santiago, una de aquellas obras es realizada junto a Alejandra Egaña, gran amiga con quien también trabaja constantemente. En la primera versión de la Bienal de Video y Artes Electrónicas obtiene el reconocimiento por Postal de Lejos y en la tercera por Comunión, parte de su trilogía Lecciones Nocturnas.

Gracias a estas Bienales conoce además a John Orentlicher, quien luego será su profesor, pues en 1995 Cifuentes es becado por la Universidad de Syracuse. Se muda entonces a Estados Unidos a hacer un Master of Fine Arts con mención en video-arte en el College of Visual and Performing Arts. Recuerda Orentlicher: "When Guillermo arrived he was more prepared than most international students in that, he spoke and wrote English very well and he had been seriously making art works with exhibitions in Chile and other Latin American countries. ${ }^{6}$

Sus amistades y su hermana coinciden en que es en ese momento donde se forma como artista, pues se encuentra con un contexto artístico muy favorable para la realización de sus motivaciones. Recuerda el mismo Cifuentes, en una entrevista realizada para la revista Chile: Arte Extremo, acerca de esta experiencia:

Fue la primera vez que me encontré con que la idea de hacer arte utilizando medios - video, cine, fotografía, computación- no estaba puesta en duda. Era un hecho. El contexto era súper exigente, lo que me obligó a aclarar las ideas, a constituir un lenguaje más mío; y, al mismo tiempo, a abrirlo hacia horizontes más ambiciosos y desafiantes. Fue increíble. Volví con una energía importante, que se me agotó a los dos años, pero, bueno... En Syracuse hice trabajos en performance, gráfica y fotografía. De hecho, mi interés por la video-instalación apareció ahí. (Lara, 2005, P.120)

\footnotetext{
${ }^{5}$ Entrevista a Claudia Aravena, (29 de septiembre 2009) por Catalina Donoso, Santiago de Chile

${ }^{6}$ Entrevista realizada por correo elecrónico a John Orentlicher (17 de septiembre 2009) por Catalina

Donoso, Santiago de Chile/New York, E.E.U.U.
} 
En efecto, al volver a Santiago, Cifuentes continúa su labor como profesor en el ARCOS y también en la Pontificia Universidad Católica. Además realiza una serie de trabajos de videoarte y video-instalación que comienzan a adquirir reconocimiento en el extranjero. Ello le permite viajar aún más, ya que sus obras son exhibidas en Nueva York, Los Ángeles, Sao Paulo, Berlín, Tel Aviv, Locarno, Beirut, Ámsterdam, Montreal y Buenos Aires, entre otras ciudades. A esto se le agrega en Chile, el haber obtenido varias veces el FONDART y la beca Fundación Andes.

Cifuentes fallece repentinamente el 27 de mayo del 2007 en un accidente de tránsito en la comuna de Providencia, Santiago. Su hermana queda como única heredera de sus obras (puesto que su madre había fallecido también poco tiempo antes) y la mayoría de éstas son de difícil acceso para el público general.

\section{Guillermo Cifuentes: el lenguaje del desarraigo}

Dentro de la obra de Guillermo Cifuentes, según el catastro realizado, se han encontrado textos académicos de su autoría, trabajos de montaje en documentales, cortometrajes documentales y de ficción, video-instalaciones y obras de video-arte. Según datos biográficos, se sabe que su producción más fecunda gira en torno a las obras en formato de video, es decir, sus videoinstalaciones y obras de video-arte. Debido a que realizó gran cantidad de obras de ambos tipos, se ha decidido enfocar el análisis sólo en sus obras de video-arte, las cuales se creen suficientes para comprender su utilización de este formato en relación a las temáticas que explora.

El análisis realizado se ha hecho a partir de un modelo de ficha de estudios cinematográficos basado en el libro Estética del cine: espacio fílmico, montaje, narración, lenguaje del teórico Jacques Aumont. Dicha ficha se ha adaptado a las características de la creación en video especialmente gracias a la ayuda del libro Del video-arte al net-art de Néstor Olhagaray. A lo anterior se suma el apoyo otorgado por el profesor y teórico Udo Jacobsen, quien tiene larga experiencia en análisis de cine experimental y cine ensayo.

A partir de esto las temáticas detectadas, que atraviesan la obra de Cifuentes desde el año 1991 hasta sus últimos videos, son la memoria individual como eje conformador de la identidad del sujeto, y el contexto urbano en relación a su uso público. Sin embargo, después de la mitad de la década del noventa se ve una crítica hacia los medios de comunicación, en particular a la televisión, y además una preocupación por ahondar en la memoria colectiva del país, en relación a las consecuencias que tiene la dictadura militar en la conformación de la identidad social.

Una constante que atraviesa la obra de Cifuentes es la utilización de su cuerpo como objeto de representación, ello en un sentido más profundo que la mera exhibición. Dicho dispositivo se puede relacionar con las perfomances al estilo Fluxus, en las que existe una interacción entre la cámara y el cuerpo del sujeto para expresar una relación entre imagen y vida.

Por otro lado, para Udo Jacobsen la utilización que realiza Cifuentes de su cuerpo lo hace 
algo más de artista plástico que el resto de los audiovisualistas, porque eso es muy propio del artista plástico, el autorretrato. Yo si lo tuviera que ligar a corrientes más generales del video-arte o de la experimentación audiovisual en términos generales, lo ligaría a los "autorretratistas".

Lo anterior se hace evidente en su obra Naturaleza muerta ${ }^{7}$, en donde más allá de las distintas poses con que se presenta el cuerpo de Cifuentes, éstas abren una reflexión acerca de la correspondencia entre el cuerpo y su imagen, como señala el texto que aparece en pantalla: “... atravesar el día, pero puedo pretender que la distancia entre yo y esta imagen es la misma que entre tuy yo que estamos situados en un punto equidistante...”

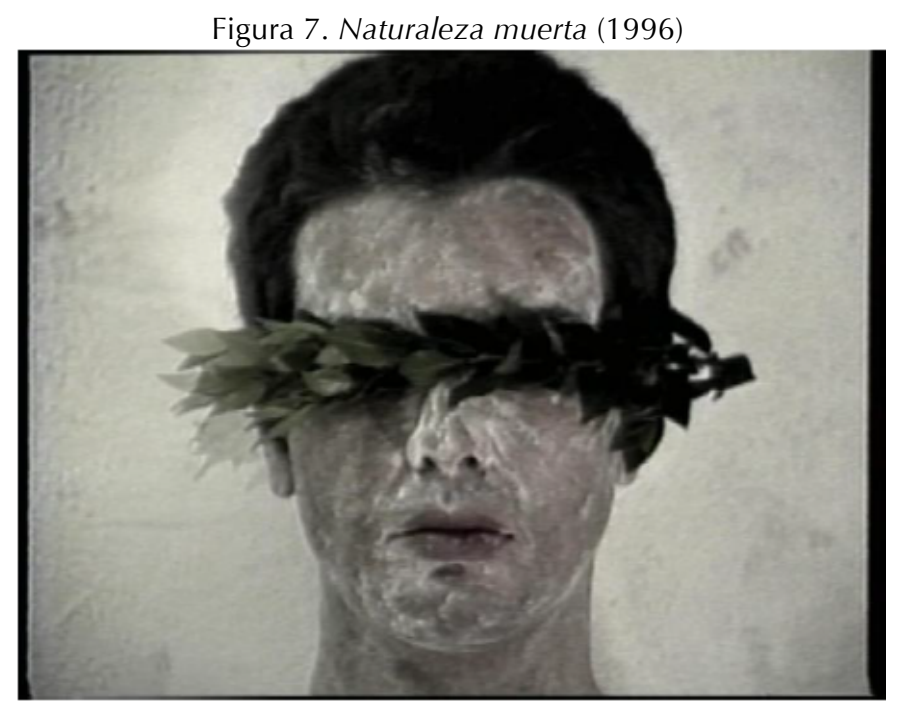

Esto induce a pensar en una observación de la propia identidad alejada del exhibicionismo y la transparencia, pues instaura un autocuestionamiento que se vuelve en la opacidad o en el abismo entre quien soy y la imagen de quien soy, es decir la imagen que en este caso dificulta develar a la realidad de su referente. Una reflexión en términos existencialistas de la identidad, que se hace presente también en su obra Release ${ }^{8}$, en donde aparece el rostro de Cifuentes

\footnotetext{
${ }^{7}$ Naturaleza muerta (10 min, 1996): Se ven imágenes de un espejo, de una mano, de la vista exterior de una ventana, de una pieza casi vacía. En ésta última se ve, en una progresión de cuadros fundidos, muchos frutos seguidos por la presencia desnuda de un joven en distintas poses. Luego se ven imágenes de un pie, de un lavamanos con las llaves corriendo. Se vuelve a ver la presencia desnuda del joven, pero esta vez a través de fundidos que lo muestran con múltiples objetos en su rostro. Se ven imágenes de un techo, de los fragmentos de un rostro y de una ampolleta circular, seguidas por las del comienzo de la obra. Todas estas imágenes son acompañas por un texto en pantalla que trata reflexiones acerca de la identidad individual, en la dificultad existente al aproximarse a quién se es, a través de una representación o imagen que más que coincidir con la vida, la construye.

${ }^{8}$ Release (11 min, 1996): Se ven pies caminando sobre la nieve. Se ve a un joven de pie fuera de una casa directamente a cámara. Se escuchan sus pasos constantemente. Luego se ve la imagen del joven de pie
} 
mirando a cámara diciendo que tiene algo que contar, relacionándose con otro hombre (que es él mismo) de manera alejada y distante, como se ve al principio de la obra en que mientras uno está frontal a cámara el otro lo está de espalda. Da cuenta de una búsqueda introspectiva de un sujeto que no se puede encontrar ni a través de su exposición a cámara (a la captura de su imagen) ni en la figura de su doble; "creo que él se ocupaba a sí mismo, como una especie de des-doblamiento porque esa imagen se transformaba en una imagen donde era él, pero no estoy seguro de que él lo viera como si fuera él, no es un espejo digamos".

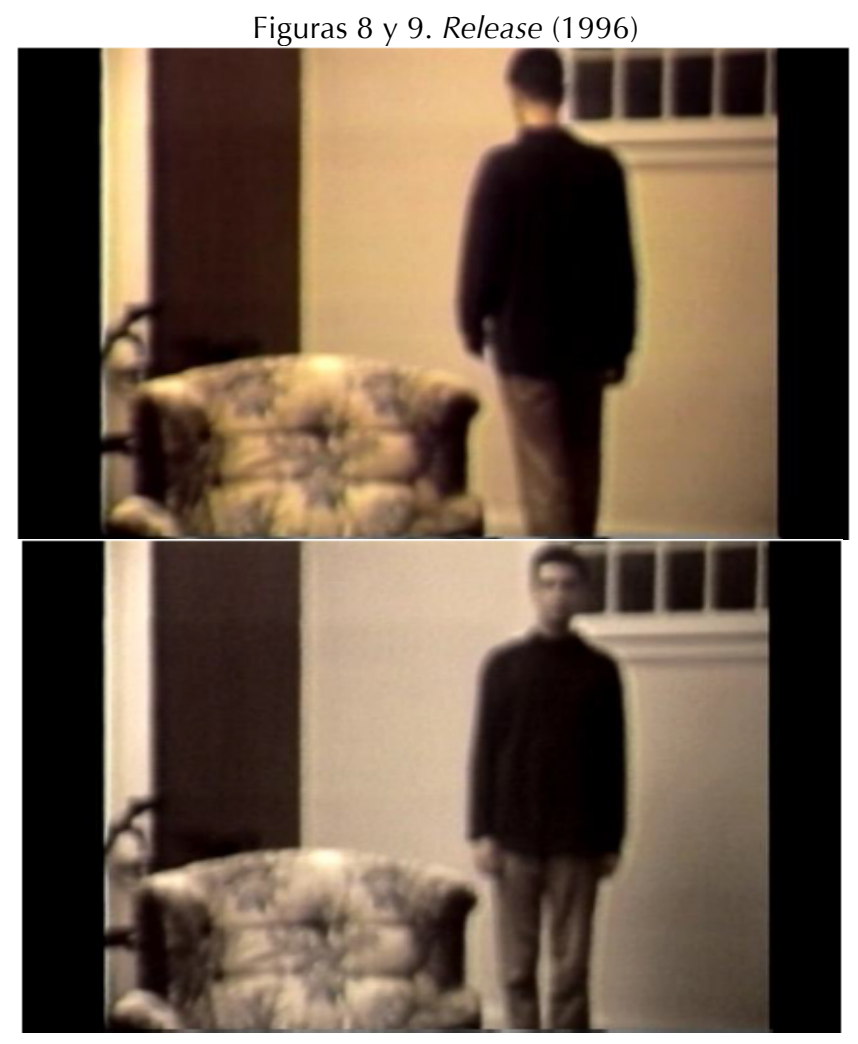

De esta forma, en Release se ve que la búsqueda de la identidad del sujeto se da en el aislamiento y en la soledad, pues este hombre representado por el artista se encuentra solo en una casa al parecer alejada de la ciudad. Esta idea, que se observa también en su obra Sueños de ciego $^{10}$, en donde la figura de Cifuentes además de aparecer fragmentada y fuera de foco (lo

intercala por la del mismo, pero esta vez de espalda a cámara. Este último se acerca al primero de forma dubitativa, cuya imagen queda congelada, pero luego vuelve al movimiento y se ve que se tapa el rostro. Se ve que camina y el otro le sigue. Entra a una casa y mira nuevamente directo a cámara, luego bebe agua de forma nerviosa. Cuenta que tiene algo que contar y que ha caminado desde lejos para ello.

${ }^{9}$ Entrevista a Enrique Ramirez (29 de septiembre 2009) por Catalina Donoso, Santiago de Chile.

${ }^{10}$ Sueños de ciego (11 min, 1997): Se ve a un joven sentado en una silla bebiendo agua de una botella sin portar zapatos, seguida de la imagen reiterada de éstos en la entrada de la casa. Se ven diferentes objetos 
que se puede decir que da cuenta de aquella dificultad en la búsqueda de la propia identidad), simula en sus poses a las de un ciego, cuya imposibilidad de ver lo aísla del exterior, dejándolo en la soledad y el desarraigo. Cabe mencionar que este trabajo fue realizado durante su estadía en Estados Unidos, lejos de sus seres queridos, según comenta su hermana, quien además afirma que él era una persona que disfrutaba el estar solo, pues en la soledad podía trabajar aquellas ideas que trasladaba a sus obras. Esto mismo hace que la gente a su alrededor lo vea rodeado de "muchos misterios. Su personalidad, su forma hacia fuera ... era muy misteriosa. Y él manejaba eso también, porque producía mucha intriga ..." (Antonia Cifuentes)

A partir de lo anterior, se puede decir que aquella dificultad de acercarse a la propia identidad, a través de la utilización de la imagen de su cuerpo, se apoya en una reflexión hacia la memoria, específicamente hacia su memoria individual como sujeto. Como afirma Udo Jacobsen:

hacía autorretrato pero uno desfasado porque es el autorretrato que superpone el recuerdo a la imagen, como es el uso de imágenes antiguas de él mismo, la búsqueda de la casa de la infancia que es lo que se produce mucho en exiliados, en hijos de exiliados, que es el desarraigo, el buscar las raíces.

Este intento se puede ver en sus obras Postal de lejos $^{11}$ y Beuys vive ${ }^{12}$, consideradas cartas visuales, donde se muestra el espacio urbano bajo un tratamiento que, a través de la alegoría del viaje y del formato Polaroid, apunta al recuerdo y a la nostalgia. Particularmente en Postal de lejos presenta su recorrido desde la casa a la escuela junto a a la figura de su cuerpo, de tal manera que se puede decir que éste último se vuelve el recipiente de su memoria y con ello, de lo que es, de suidentidad.

Era un trabajo que reclamaba el derecho a la intimidad y a un imaginario personal, donde simplemente grabé el recorrido hecho de mi casa a la escuela, todos los días. El tratamiento de la imagen era plástico. Representaba un estado de ánimo, una historia de desarraigo y traslado que tengo. (Lara, 2005: 123)

Postal de lejos fue la primera obra de Cifuentes considerada video-arte, donde destaca la

de una casa. Luego ven partes de la imagen fuera de foco del joven realizando gestos que simulan los de un ciego (se tapa la vista con la mano y espinas, tantea el espacio con su mano). Finalmente, el joven quema los zapatos y aparece fumando.

${ }^{11}$ Postal de lejos (5 min, 1991): Un joven en primer plano mira a cámara, sobre él pasan rayas como si fuese la grabación de una pantalla. Se escucha una voz femenina que canta una triste melodía, mientras se ven pasar imágenes de edificios, casas, calles abandonadas.

12 Beuys Vive (9 min, 1992): Se ven vistas subjetivas y sobre-expuestas desde un tren en marcha junto a una voz femenina anunciando la partida de los trenes en alemán. Se ve en realenti un tumulto de gente bajándose de un bus y transitando en la calle. Se ve la ciudad sin personas. Se repiten las imágenes del tumulto de gente y las vistas subjetivas desde el tren, pero ahora más realentadas aún. Luego se ven travellings de árboles, postes y techos de casas. Se escucha una música tipo mambo mientras se muestran metales y líneas de una estación de tren. Finalmente se ven textos escritos sobre los muros de la estación de trenes y se repiten las imágenes de las líneas del tren, ahora casi en silencio. 
forma poética de mirar su recorrido cotidiano, dejando entrever los recuerdos y memorias que está conforma. Hay tristeza y melancolía en esta obra, especialmente por su musicalización, una opera de voz femenina, cosa que Cifuentes usa muy poco en obras posteriores.

De Beuys vive se puede reconocer una temática transversal a la obra de Cifuentes: el espacio urbano. En ella, a través del recuerdo, desarrolla una percepción subjetiva de la ciudad y de sus habitantes, donde éstos producen en el observador la sensación de extrañamiento al transitar de forma fría y distante, sin rastros de interacción entre ellos. Cabe señalar que dicho extrañamiento nace y se desarrolla a lo largo de la obra de Cifuentes: éles un hijo del exilio que desde muy pequeño ha construido su vida en distintos países (Noruega, Alemania y Ecuador) antes de llegar a Chile. Al igual que en Postal de lejos, en Beuys vive se revela una cierta tristeza en la obra pero un año después y en Alemania: se demuestra así lo mundano del artista y como ello reforzó de la idea del desarraigo. Cifuentes nos muestra que la vida del hijo del exiliado está siempre ligada a una cierta soledad y sensación de no pertenecer. Durante los años 1993-1996, recién egresado del Instituto ARCOS, Cifuentes mantiene un intercambio de cartas audiovisuales con su compañera de generación Claudia Aravena, quien se había instalado en Berlín, Alemania. Así, a propósito de la video-instalación Lugar común (fruto de estas cartas visuales), Aravena señala que en aquella se muestra: "la percepción de la ciudad donde estás viviendo, de vivir, habitar ese lugar, con la sensación de extrañamiento propia que tenía el no ser de ahí". Es, en definitiva, la mirada del turista, un visitante quien inevitablemente no pertenece.

En Have you ever imagine the future would look like this $?^{13}$, Cifuentes utiliza tres líneas de texto sobre la pantalla. En una de ellas plantea la idea de la pérdida de interacción entre los sujetos en el espacio urbano. Asimismo, habla de una pérdida de identidad en los transeúntes: sujetos anónimos que no interactúan y que así transforman a la ciudad en un mero lugar de tránsito. Se destacan frases como: "¿Cuando fue la última vez que hablaste con un desconocido?, ¿cuando fue la última vez que compartiste pensamientos honestos con un desconocido?, ipor qué nos parecen más reales los estacionamientos de un mall?". Al respecto, en su artículo "Sitios Baldíos" publicado en la compilación Arte y política, señala: "El empobrecimiento de nuestra noción de espacio público, y de sus usos posibles (relegados a la protesta política directa, entregada, sin contrapeso, a la parafernalia publicitaria) reclama atención crítica propositiva desde el arte" (Cifuentes, 2005: 307).

\footnotetext{
${ }^{13}$ Have you ever imagine the future would look like this? (4 min, 1996): Se ven imágenes capturadas directamente de la televisión estadounidense que muestran publicidad, fragmentos de películas y noticiarios interrumpidos por cuadros en negro. Ello junto a la presencia en pantalla de tres líneas de textos que pasan de derecha a izquierda de cuadro. Cada línea aborda distintas temáticas: la superior habla en primera persona acerca de deseos consumistas, la del medio apela a preguntas directas al espectador referentes a la pérdida del espacio público, o mejor dicho de su desuso y la última, en primera persona del plural, se refiere a una añoranza por pasado mejor, donde el mundo y las relaciones sociales parecieran ser más humanizadas.
} 
Figura 10. Beuys vive (1992)

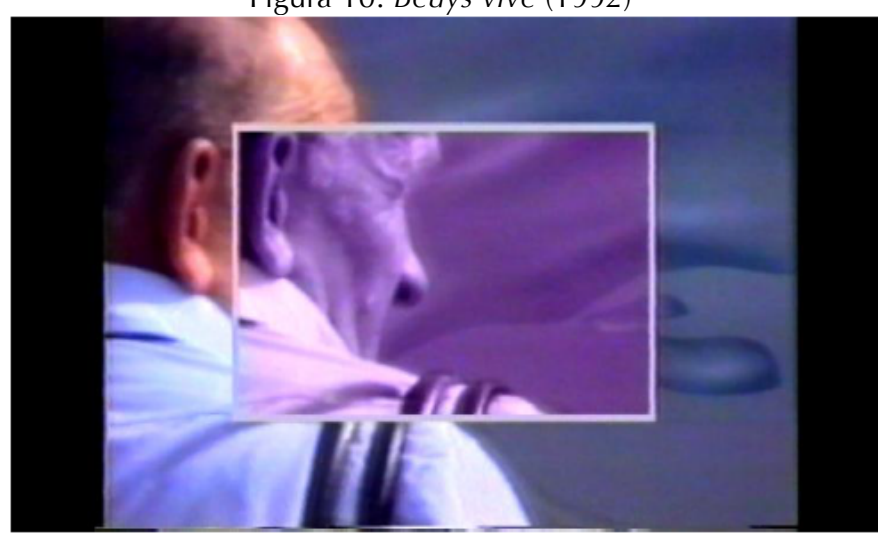

Figura 11. Have you ever imagine the future would look like this? (1996)

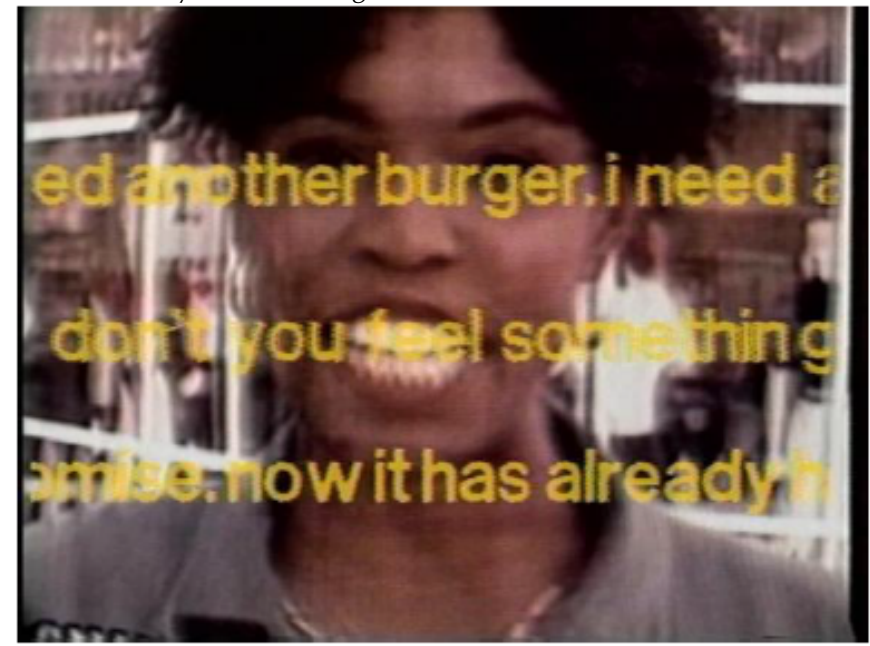

Por esto es que Three corners: study for a circle $1^{14}$ es dedicada de forma especial a realizar una reflexión acerca de la perdida del espacio público, en relación estrecha a su perdida de originalidad e identidad. La obra, visualizada en Los Angeles, muestra el museo Disney Hall, presentado con un valor histórico identitario y por ello de alguna manera representa cierta idiosincrasia. Luego un estacionamiento, que finalmente cobra mayor presencia en la obra, por ser un lugar mucho más frecuente en las ciudades y que desarrolla la idea de ser un lugar de tránsito que produce que los sujetos queden en el anonimato.

\footnotetext{
14 Three corners: study for a circle 1 (10 min, 2004): Se ven, en pantalla dividida, planos fijos de las afueras del museo Disney Hall (que solía ser un estacionamiento de autos), de un estacionamiento rodeado de edificios (donde solía estar la filarmónica de la ciudad) y de otro estacionamiento. Todos aquellos lugares situados en Los Ángeles. Finalmente el último lugar se sobrepone a los otros y se muestra en cámara rápida. Lo anterior es acompañado por un texto en pantalla que reflexiona acerca del contexto urbano, como un lugar público que ha perdido su identidad.
} 
Figuras 12 y 13. Three corners: study for a circle 1 y 2 (2004)

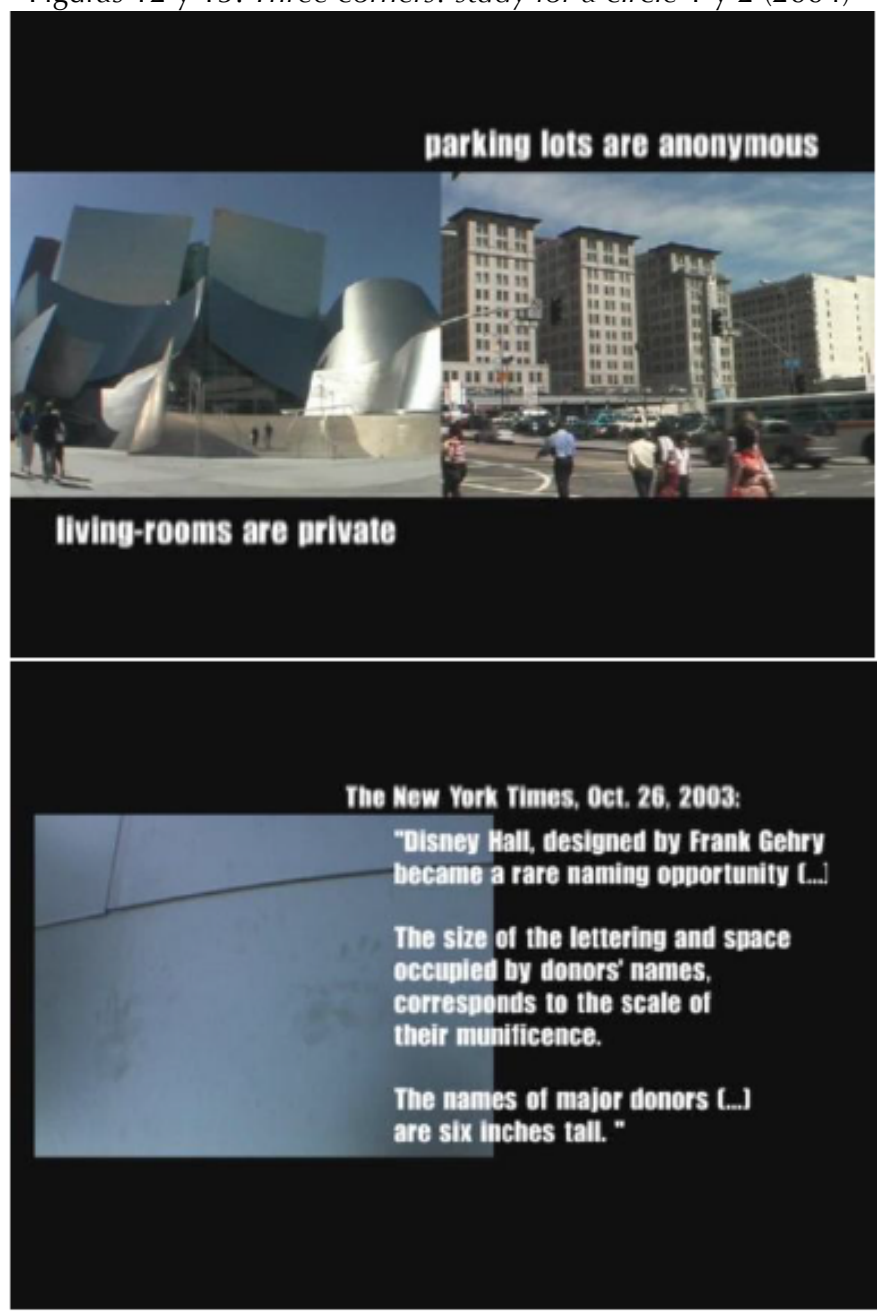

Este mismo juego de anonimato continúa en Three corners: study for a circle $2^{15}$, donde se ven las murallas del Disney Hall marcadas por huellas de manos, representando una subversión motivada por el anhelo de los visitantes de volver a hacer público dicho espacio, sin tener que entrar en el sistema de donaciones del museo. Ello porque sólo personas que realizan las mayores donaciones (cientos de miles de dólares) son reconocidas con la inscripción de su

\footnotetext{
${ }^{15}$ Three corners: study for a circle 2 (10 min, 2004): Se ven, en pantalla dividida, imágenes de las paredes blancas del museo Disney Hall con manchas de manos sucias, las cuales son sucedidas por imágenes de autoridades y gente viendo las huellas. En la otra pantalla se ven textos sacados de la prensa escrita estadounidense que cuentan cómo las personas que han donado dinero a dicha institución tienen inscrito su nombre en el museo. Lo anterior acompañado por la presencia de un texto en pantalla que reflexiona sobre que la ciudad está fragmentada, pero que el museo Disney Hall une a sus habitantes.
} 
nombre sobre las murallas, cuyo tamaño es proporcional al monto donado. Cifuentes denuncia así el elitismo de la sociedad de consumo que, finalmente, influye en las formas de ocupar la ciudad. Como él mismo señala en una entrevista:

Apareció con fuerza cómo lo urbano se ha ido convirtiendo en una abstracción que corresponde a cierta visión de una clase hegemónica. Los aeropuertos se parecen unos a otros cada vez más. Los malls. Los cines. El espacio de la mercancía como que requiriera ser homogéneo. Y junto con eso se producen fisuras, ocupaciones inadecuadas, incluso subversivas; modos de uso de la ciudad que son anómalos, espacios mudos - como el terreno baldío- que no pueden ser recuperados. La ciudad es historia, pero también es expresión de un deseo; sobre todo las ciudades capitales: hablan de lo que hemos sido y de lo que queremos ser. (Lara, 2005: 124)

Esta crítica hacia la clase hegemónica y la sociedad de consumo también se puede ver trasladada a una crítica hacia los medios de comunicación, como se ve en la mencionada Have you ever imagine the future would look like this? En ella, las imágenes televisivas en que se ven, por ejemplo, comerciales para ser bello y pasatiempos burgueses como el golf, son descontextualizadas mediante el montaje, haciéndose altamente reflexivas y críticas hacia la sociedad mediatizada y consumista. Una de las líneas del texto en pantalla apunta hacia deseos sumamente consumistas e incontrolables: "necesito una cerveza", "necesito adelgazar", "necesito una hamburguesa”. Se puede decir que la descontextualización de aquellas imágenes obedece a un afán por subvertir los códigos que utiliza la televisión. El propósito es criticarla con los mismos dispositivos representacionales que posibilitan sus reglas de entendimiento, es decir su verosimilitud. Esa apariencia de verdad se ve avasallada de manera similar a la de Nam June Paik, en los inicios delvideo-arte.

El caso anterior se observa también en la trilogía de Cifuentes Lecciones nocturnas, la cual se compone de Comunión, Primera lección y Un puente que cae. Esta obra es de gran importancia ya que es la que más se ha mostrado en Chile y el extranjero. Comunión gana el tercer Concurso Juan Downey de La Bienal de Video y Nuevos Medios. Esta trilogía puede considerarse como uno de sus trabajos más evidentemente políticos, puesto que recicla material de archivo sobre casos de violencia política en Chile, en especial aquellos pertenecientes a la época de la dictadura. En una entrevista Cifuentes afirma que su interés por dicho material es que muestra:

una historia que he conocido siempre mediada. Nunca la viví directamente, sino a través de registros. Por esto, me empezó a interesar qué es lo que se juega en la representación de la historia, qué se muestra, qué se oculta y cuáles son las contradicciones. (Lara, 2005: 123) 
Figura 14. Comunión, de la trilogía Lecciones nocturnas (1997-1998)

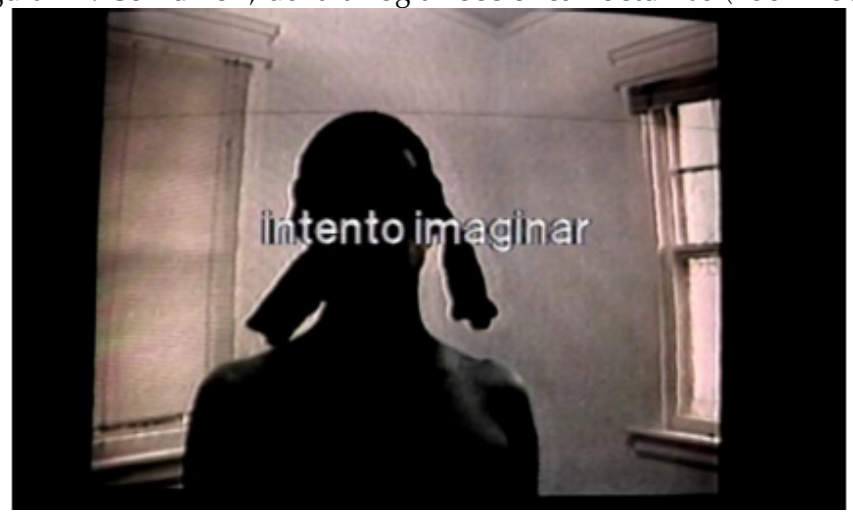

Figura 15. Primera Lección, de la trilogía Lecciones nocturnas (1997-1998)

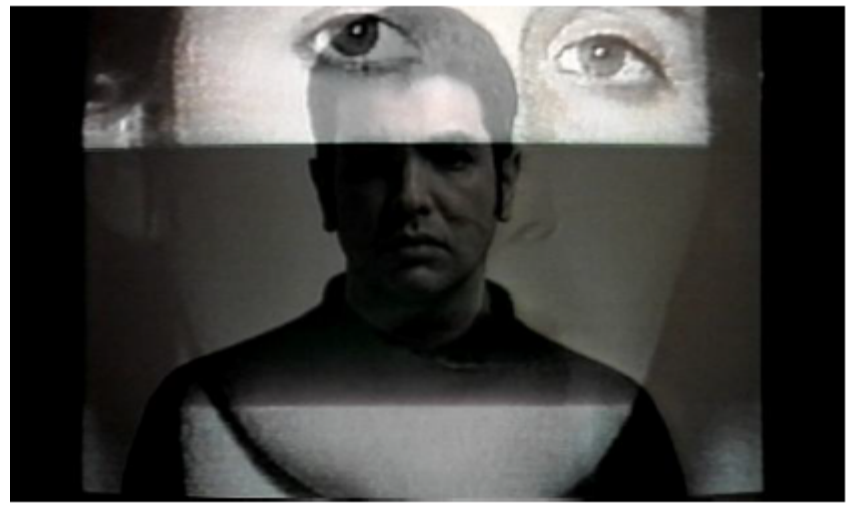

Figura 16. Un puente que cae, de la trilogía Lecciones nocturnas (1997-1998)

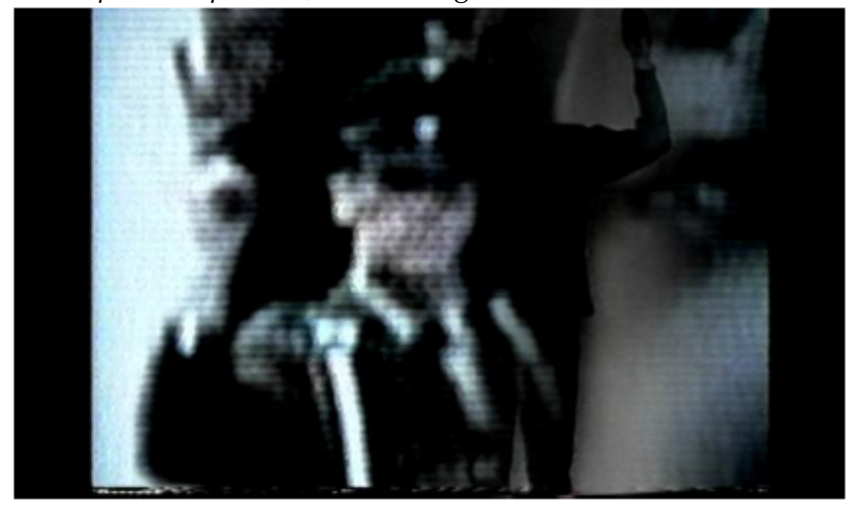

Así, dicha historia es interrogada, es vuelta a traer al presente de forma crítica y cuestionadora, no tanto a los individuos específicos que participaron en ella como a las relaciones de poder que se establecen dentro de ella, particularmente dentro de la esfera de la autoridad política. Según Carlos Ossa, se hicieron cómplices de los medios de comunicación 
(en efecto, los que tienen el privilegio de enunciación del discurso oficial) para negociar la verdad histórica de manera hegemónica y autoritaria. Ello porque, a pesar de algunas pocas emisiones públicas (como el mencionado material televisivo que recoge Cifuentes), se esmeraron en invisibilizar el terror y el dolor de las víctimas de la dictadura en tanto cuerpos: prisioneros, torturados, cadáveres, desaparecidos. Cifuentes construye una crítica hacia todo el aparato discursivo en tanto que éste, al decidir cómo se debe contar la historia, decide también cómo y qué de ella quieren que entiendan los individuos/espectadores. Para John Orentlicher:

These tapes are best described by trying to feel the individual pain of individuals who had had specific experiences of injustice, torture or criminality at the expense of the junta as a way to acknowledge he was in exile and did not share in these abuses at the time they occurred.

En efecto, Cifuentes utiliza la representación de su cuerpo en estos videos para intentar ponerse en el lugar del otro con la humildad del que no vivió esa historia, pero que busca de forma personal y subjetiva comprenderla. Cabe recalcar que, si bien él vivió la dictadura en el exilio, siempre estuvo muy conectado con lo que pasaba en Chile según relata hermana. Por ello puede decirse que Lecciones nocturnas no es tanto el préstamo de una historia no vivenciada, ya que él si la vivió pero de forma indirecta: dada la experiencia de sus padres y la suya propia, esta historia lo afectaba de todos modos. Esta obra inaugura en sus reflexiones la temática de la memoria colectiva, pero siempre unida a la individual, que explora desde sus primeras obras. Como señala su amiga Claudia Aravena:

él se instala dentro de los trabajos, donde este sujeto de la enunciación se convierte ahí en un objeto de la representación, él entra y hace suya de alguna manera la representación. Hace suya esa historia, apela de alguna manera al derecho de contar su historia con sus propias palabras, propia visión, apelar a esta ... y no a la historia, la historia con mayúscula, la historia entre comillas.

Para su hermana, la motivación de contar la historia a su manera no existe solo en Cifuentes, sino también en otros artistas coetáneos, quienes, siendo también hijos del exilio, vivieron de manera muy profunda una serie de interrogantes respecto de su identidad, sumado a la tortura, muerte o desaparición de gran mayoría de (por no decir de todos) sus familiares y amigos. Dicho cuestionamiento de la propia identidad se puede ver en Primera lección ${ }^{16}$ en donde se repite una voz-off que dice: “¿Cuál es tu nombre completo? ¿Cuál es tu nombre político? ¿Con qué cédula de identidad fuiste detenida, con qué nombre? ¿Quién te proporciona esa

\footnotetext{
16 Primera lección (9 min, 1997-1998): Se ve la imagen capturada de la televisión de Karen Eitel, joven torturada durante la dictadura militar, durante los primeros segundos de su interrogatorio público (registro tomado de Teleanálisis, noticiero de la época hecho en video). Dicha imagen se ve realentada y tapada por una banda oscura que corre constantemente hacia arriba del cuadro, como simulando un "escáner" a la imagen. Además se ve con zoom y filtros de textura. Lo anterior es intercalado, mediante sobreimpresiones, por la imagen de un joven que parece querer simbolizar el dolor de la tortura de Karen (éste mira a cámara, sacude su cabeza de un lado hacia otro, se pone una venda y grita).
} 
identidad?" ante la imagen escaneada una y otra vez de Karen Eitel (joven que fue interrogada en tales términos de forma brutal), fragmentando la misma en varios sujetos. Esto parece abrir en Cifuentes la pregunta existencial de ¿quién es Karen Eitel? o más bien dicho ¿quién era Karen Eitel? ¿La imagen de este registro es Karen Eitel? Esta percepción difusa del pasado, Cifuentes la intenta traer al presente a través de gestos y posturas de su cuerpo que parecen querer responder a esas interrogantes, de forma que aquellas revelen la identidad de la mujer, lo reprimido en el momento de su interrogatorio, gestos que expresan un fuerte dolor: mira a cámara, sacude su cabeza de un lado hacia otro, se pone una venda y grita. Pero asimismo ellos se ven interrumpidos por constantes congelados de imagen que instauran una dificultad en el adentrarse a aquel pasado, a aquella identidad.

Según Carlos Ossa, este deseo constante de retornar al pasado que se observa en Lecciones nocturnas es motivado por la incapacidad colectiva de hablar del dolor y el consecuente olvido, que han propagado los medios de comunicación. Así, para Cifuentes se hace necesario volver a abrir la herida: no referirse a ella impide su real cicatrización, su real superación, lo que la hace pervivir el presente en un silencio violento y doloroso. En este sentido, el teórico señala que Cifuentes crea

una imagen que politiza el montaje ahí donde la única política de la memoria es volver a montarla y en ese plano entonces entra esta pretenciosa histeria transicional que quiere cerrar todos los capítulos, Cifuentes nos dice la historia hay que contarla mil veces porque es necesario.

Asimismo, a esta imagen de la memoria no se la puede tildar ni de victimista ni de absolutista, pues Cifuentes se aleja de su utilización como testimonio para crear, en este sentido, diferentes estrategias de la memoria. Ello se puede ver en $U_{n}$ Puente que $\mathrm{cae}^{17}$, donde se muestra la imagen de un carabinero en postura autoritaria alzando una pistola con el brazo, sobreimpresa a la imagen de Cifuentes imitando el mismo gesto, y con ello intentando ponerse en el lugar de ély no sólo de las victimas. Pues para hablar de un tiempo doloroso, Cifuentes sabe que no hay respuestas definitivas y totalizadoras. De forma recatada, intenta aproximarse a las heridas de aquellos cuerpos, aproximarse a sus motivaciones, sus sentimientos, sus recelos ... lo que para Carlos Ossa responde a una deuda que tiene Cifuentes consigo mismo por no haber vivido esa historia de forma directa y que por ello mismo no puede traer a la memoria de manera completa.

\footnotetext{
${ }^{17}$ Un puente que cae (11 min, 1997-1998): Se ven imágenes "borrosas" (debido al uso de realentado combinado con filtros de textura, un efecto que la hace tiritar, movimiento de zoom y sobreimpresiones) de la indignación pública luego del baleo de carabineros hacia María Paz Santibáñez frente al Teatro Municipal (registro tomado de Teleanálisis), intercaladas con las de un joven que simula los gestos de dichas personas. Ello acompañado de un texto en pantalla que reflexiona metafóricamente sobre la figura del puente, en tanto que en un lado se puede situar la historia (el pasado) y en el otro el presente. Pero entre ambos algo no llega a conectarse, un puente cae.
} 
Por ejemplo, en Comunión ${ }^{18}$ aparece un texto en pantalla que dice: "quiero conocerte, quiero que te vuelvas, y me hables, háblame, atravesando estos gestos, háblame, atravesando estas líneas, atravesando estas líneas divisorias, líneas de culpa, líneas de culpa, culpa asumida, rehusada, negada”. Estas frases, sumadas a la presencia de Cifuentes simulando las posturas de los cuerpos de los torturados con una venda que le esconde el rostro, parecen apuntar a dicha suerte de abismo que se teje entre pasado y presente, en el intento de unirlos y poder así ver la historia de manera global. En Un puente que cae se observa esta idea de forma bastante parecida: el mismo título de la obra apunta hacia la metáfora del puente que cae como una imposibilidad de unión entre una orilla y la otra, entre presente y pasado, como señala el texto en pantalla: "this is history, the body repeating, the pulse of another, on this bank of the river, the gestures are empty, the trace of another trace, the sign of another sign, guilt is like innocence, impossible, this is the present, a falling bridge, a bridge of gestures written on water, this is history, blind, mute, Iglide”.

Es importante señalar al respecto de la memoria colectiva, como temática en la obra de Cifuentes, que ésta cobra un mayor desarrollo en sus video-instalaciones, de las que cabe destacar: Reconocimiento de lugar (2002), Lanzados (2004) y Sin título: (brisas te cruzan) (2005).

Ahora bien, para adentrarse en el lenguaje que crea Cifuentes en las obras mencionadas anteriormente, es necesario recordar que el video-arte se constituye como soporte caracterizado por una materialidad más cercana a la abstracción y más versátil que otros soportes. Ello posibilita que se le trabaje conceptualmente, sobre todo con las herramientas de postproducción. Al respecto, Cifuentes señala:

Así, desde la vertiente del hacer, en mi trabajo el procesamiento de la imagen no es tanto un asunto de pictorialización (de la movilización de los códigos de la pintura o las artes visuales en general) como del asentamiento y acumulación de las marcas de una relación activa con el material, desplegada en el proceso de trabajo. Una marca temporal, la huella de la densidad del tiempo de trabajo, de un diálogo, que reditúa un enriquecimiento sensorial de la superficie representacional misma. (Cifuentes, 2007: 3)

Esto se puede ver por ejemplo en Un puente que cae, donde priman entre y dentro de las imágenes ciertos cortes fantasmagóricos -por así llamarlos-, ya que alejan a la imagen de una

18 Comunión (13 min, 1997-1998): Se ve a un joven de espalda que se mueve incómodo intentando sacarse la polera para luego quedar con la espalda descubierta. Se ve que se venda los ojos y realiza posturas que simulan las de los cuerpos torturados durante la dictadura militar. Luego se ven imágenes tomadas de los registros de la reconstitución de escena del "caso degollados" emitida por el programa de televisión Informe Especial: aparece un hombre acuchillando a otro acostado en el suelo, una mujer Ilorando, otra (Estela Ortiz) hablándole a alguien de cómo ha sufrido mucho, un hombre caminado y otro leyendo un libro. La mayor parte de estas imágenes son sucedidas por sobreimpresiones y fundidos a negros, además de que las mismas presentan filtros de textura, fuera de focos y realentados. La obra finaliza con la imagen del principio de la obra. Todo ello acompañado de un texto en pantalla que, en primera persona, interpela al espectador con frases referidas a que observa sus cicatrices, pero hay una barrera que impide conocerlas de fondo, lo cual intenta imaginar. 
nitidez que posibilite su comprensión. Así, se ve a la muchedumbre en la calle junto a la figura baleada de María Paz Santibáñez, de forma bastante borrosa, muy cercana a la abstracción: hay un uso de fundidos encadenados, sobreimpresiones y diversos filtros. Ellos ayudan efectivamente a trabajar conceptos como los de memoria colectiva e individual, que se presentan en esta obra.

Cifuentes, al venir de una escuela que lo formó especialmente a través de la semiología y el análisis de la imagen, tempranamente (desde su tesis El fuera de campo y la dialéctica del espacio) manifiesta una inquietud con respecto a las posibilidades propias del lenguaje audiovisual, en el sentido de la búsqueda de sus potencialidades expresivas. Pese a que esta idea nace de su acercamiento al lenguaje cinematográfico, puede verse también reflejada en su creación en video, cuyas capacidades expresivas las relaciona íntimamente con la idea de la memoria, que trabaja a lo largo de todas sus obras.

Así en su texto “Anillo de Moebius”, publicado en la compilación Arte y medios audiovisuales un estado de la situación, trabaja la idea de que al video le es imposible separarse del transcurso temporal de los acontecimientos que replica. Ello construye una imagen cuya particularidad guarda estricta dependencia con la lentitud del tiempo presente volviéndose pasado. Esta idea está inspirada por el “cuento delvidrio lento”, que el propio Cifuentes explica así:

Un cristal tan denso que sería capaz de retardar el paso de la luz en varios años, de manera que una ventana hecha de él se abriría siempre hacia el pasado, hacia aquello que alguna vez aconteció ante ella y ya no volverá más. Una tecnología imagética de la memoria basada en la lentitud. (Cifuentes, 2007: 6)

Esto genera la diferencia del video con la fotografía, que referencializa los acontecimientos al capturar solo un instante de su transcurso temporal, produciendo así una separación entre copia y modelo. El video, al no producir del todo dicha separación, apunta entonces a una permanente fuga del tiempo, que de esta forma corporaliza lo real, resultando una materialidad fluctuante entre la representación y la experiencia, entre lo objetivo y lo subjetivo. En definitiva entre el lenguaje y la realidad.

Las superficies de la moneda se abren la una hacia la otra, no puedes decir si estás despertando o cayendo en el sueño. La imagen video transita así entre el mundo de la coherencia simbólica y la gravitación del imaginario hacia el exceso del real, constituyendo en el transitar, en el cruce y recruce de la frontera, un umbral entre ellos. (Cifuentes, 2007: 3)

Es el anillo de Moebius que borra las diferencias entre un afuera y un adentro, así como el video-arte de Cifuentes explora los límites entre el presente y el pasado, el sujeto y su entorno.

\section{Reflexiones finales}

A través de la investigación realizada, se ha logrado concretar el catastro de todas las obras de 
video-arte de Guillermo Cifuentes. Además, se ha hecho una profundización en subiografía -de suma importancia para comprender su mirada- y del contexto artístico que lo enmarca. Realizado lo anterior se ha analizado la obra de video-arte tanto en sus aspectos conceptuales como formales, para comprender las temáticas que aborda en conjunto con el lenguaje audiovisual que las caracteriza.

La obra de Guillermo Cifuentes presenta temáticas atravesadas por lo político: su acontecer visto en la dictadura y en la vuelta a la democracia. Así, la memoria colectiva histórica está fuertemente desarrollada en Lecciones nocturnas y en sus video-instalaciones, temáticas que durante muchos años significaron censura o detención y que aún en democracia son complejas y llenas de dolor, pero que al recontarlas, significan para Cifuentes una verdadera cicatrización de la herida que representan. Al respecto su amigo Enrique Ramírez destaca:

Y la relación que él tiene con el arte y la política, para mí es todo lo que él era, o lo que él es, es él, nosotros siempre hablábamos de eso. Es algo que a mi me interesa mucho también. Es algo que decíamos, que cada artista tiene que tener los dos pies sobre la tierra y saber donde está pisando.

De ahí también la preocupación que siente por la convivencia urbana, por cómo los sujetos se relacionan en la ciudad de una forma en que se pierden unos a otros al no interactuar entre sí. Ello, porque la disposición espacial de dicho lugar lo imposibilita: estacionamientos, aeropuertos y carreteras impiden la concretización de encuentros. No por nada su hermana afirma que desde muy pequeño él tenía:

una relación así muy potente con los lugares, le encantaban los lugares, salíamos a caminar ponte tú, a mirar edificios; mira, aquí hay una gárgola, mira, aquí este pasaje ... o sea como, me imagino yo que era como tratar de imaginarse todas las vidas de todas las personas, o sea, como una cuestión muy de la ciudad. (Antonia Cifuentes)

Cabe destacar su especial capacidad de tocar estos temas de forma crítica, pero sin caer en una mirada victimista ni totalizadora, sino tanteando y poniéndose en el lugar de todos los bandos. Por otro lado, se identifica una crítica explícitamente dirigida hacia los medios de comunicación, en cuanto a su rol en la construcción de la memoria colectiva, es decir, de la historia oficial. De lo cual se desprende esta temática como importante en la obra de Guillermo Cifuentes, por apuntar a la actual sociedad de consumo y cómo esta construye la vida de los sujetos de forma hegemónica. Por esto es que se puede afirmar que su obra es política no solo en el sentido más evidente de enfocarse en el tema de la dictadura, sino por profundizar algo mucho más invisible a primera vista y a la vez global: el cómo las relaciones de poder (ya sean las autoridades políticas, los medios de comunicación o la historia del arte) construyen un discurso que mediante el consenso se hace verosímil y hegemónico.

En efecto, además de una crítica temática se puede encontrar en la obra de Cifuentes una crítica más bien formal, la cual se ve en cómo utiliza el lenguaje audiovisual para desestabilizar sus códigos de legitimidad (es decir, los códigos que permiten su inserción en lo que se suele 
llamar arte). Así en su obra se ve frecuentemente la utilización de material televisivo intervenido mediante a herramientas de postproducción, de manera tal de alterar los códigos representacionales que hacen sus mensajes unidireccionales y transparentes llevándolos más a la abstracción y evitando una lectura totalizadora. Ello lo realiza con un constante uso de herramientas de montaje y postproducción, tales como difundidos encadenados, sobreimpresiones, utilización de textos en pantalla y el mencionado uso de imágenes grabadas de la pantalla televisiva cuya textura delata su referente. Es así que su obra puede llamarse con derecho como de video-arte, según el análisis teórico realizado, al trabajar sobre los parámetros técnicos del soporte. Por ejemplo, en Primera Lección el escáner que presenta la imagen hace analogía con la idea conceptual de la vigilancia y del interrogatorio de la identidad de forma tal que la materialidad del soporte aborda así ideas bastantes complejas. Y que de igual forma se presentan con una poeticidad que atraviesa el conjunto de su obra de manera tal que se aleja de las estructuras narrativas tradicionales para concentrarse con libertad y de forma doméstica en trabajar la alteración de la imagen.

Esta distancia hacia el cine de alguna forma muestra una suerte de incomodidad que siente Cifuentes con el arte como una institución que a fin de cuentas decide qué es arte y qué no, por ello puede decirse que éste según Claudia Aravena:

se sentía incomprendido a veces sin razón, fue algo que lo conversábamos mucho, porque esa parte era algo que le interesaba bastante, la reflexión critica, él no hacía arte para acumular obras, él de hecho a veces paraba, y dejaba pasar un rato. Él no era de esos artistas que tiene como una especie de pulsión constante, a veces tomaba distancia y luego volvía.

Cabe decir que Cifuentes cuando abre la herida de la dictadura cuestiona dicha historia bajo sus propias reinterpretaciones, es decir desde una visión estrechamente personal y subjetiva. Por ello mediante a un montaje rítmico y lleno de metáforas y analogías intenta unir las imágenes de esta historia con las de su propio cuerpo, a fin de tender un puente entre el pasado y el presente y así mismo, entre la memoria colectiva de un país y en cómo ésta afecta a la individual. De esta manera se explica que el hecho de que a lo largo de su obra Cifuentes utilice constantemente su cuerpo como objeto de representación es porque éste es el recipiente de su memoria como sujeto individual. Su autorretrato habla del individualismo, de la soledad del sujeto contemporáneo y la flexibilidad que le impone la mundanidad del exilio. Pero de manera problemática puesto que en su obra existe una distancia y no correspondencia entre la imagen del cuerpo representado y su identidad.

Este desplazamiento compromete mi cuerpo y requiere que le reasigne su protagonismo, en su calidad no solo de contenedor y receptáculo sino de articulación (bisagra) y de operador principal de nuestra experiencia perceptiva. Guillermo prolonga y densifica este momento, sabe que en definitiva el cuerpo va al encuentro de la memoria sólo en un estado de afección. Comprometer el cuerpo en la afección, llevarlo hasta la torsión que posibilite pasar a otra dimensión; a la de la memoria... (Olhagaray, 2007: 4) 
¿Cuál es entonces el ejercicio al que nos somete Cifuentes a lo largo de toda su obra? Es justamente el de mirar a los sujetos y a sí mismo desde la distancia, es decir desde la idea del desarraigo y no pertenencia, que siente un hijo del exilio y que así mismo la reproduce tanto en la relación del presente con el pasado, con la memoria, como también con el anonimato de los sujetos en la ciudad que transitan como si ésta impidiera posibilitar cualquier relación entre ellos. De ahí mismo las sensaciones de dolor y tristeza que se desprenden de un lenguaje que, a manera del anillo de Moebius, imposibilita la total comprensión dado a la indiferenciación entre la realidad y la ficción.

Como bien afirma Cifuentes:

el estar en el mundo es concebible como una eterna intersección, un cruce en permanente deslizamiento (en constante flujo) entre sujeto y objeto. El cuerpo, como límite e interfaz, y el mundo, cuyos objetos adquieren su sentido profundo solo en su encuentro, en su transitar por nosotros, aparecen entonces como dos dimensiones que recaen permanentemente la una de la otra, desintegrándose a medida que se alejan del plano de su intersección: esa superficie imaginaria, donde tanto objeto como sujeto adquieren su sentido en la estabilización provisional de la experiencia, es el sitio de la identidad, de la biografía, de la subjetividad como ficción de lo unitario. (Olhagaray, 2007: 4)

Guillermo Cifuentes es parte de una generación que a inicios de los años noventa se encuentra en un nuevo escenario político que les permite expresarse por cierto, pero que por otro lado los obliga a crear una carrera artística sin mucha guía, como bien las escuelas habían sido cerradas por el golpe militar, su re-apertura significa un auge en posibilidades pero también una falta de experiencia para las nuevas escuelas. Por ello es que muchos de ellos desarrollan parte de su carrera en el extranjero donde se perfeccionan y conocen las tendencias artísticas que predominan en otros lugares. Concibiéndose así como una generación de artistas más bien internacionales. Esto además remarca la importancia que se le otorga a la memoria en las obras de Cifuentes, quien llega a Chile en un momento histórico que recién comienza a descongelarse luego de haber tenido que cerrar los ojos por muchos años.

Asimismo los realizadores que utilizaban con anterioridad este formato con la vuelta a la democracia lo abandonan para acercarse al cine y a la televisión antes clausuradas. Pero vale recalcar que ellos lo utilizaron solo con un afán de denuncia de dicha situación. Así la nueva generación se caracteriza por haber sembrado el escenario del video-arte en Chile, al abrir el uso de este formato a las posibilidades artísticas que en él se hayan latentes, lo que se muestra en los trabajos de gran calidad estética que se presentan en los Encuentros de Video-Arte FrancoLatinoamericanos que nacen en dicha época. Y para Néstor Olhagaray como para Claudia Aravena, Cifuentes se presenta como uno de los actores más destacados, como afirma el primero:

Guillermo representa precisamente una reinauguración del uso del video en el arte local al no constituir precisamente una filiación de esa generación. Guillermo forma parte de aquellos nuevos artistas que 
irrumpen en la escena gracias a su labor vanguardista. Tiene el merito de hacer que el video-arte entre definitivamente en la escena artística. (Olhagaray, 2007: 8)

Así puede decirse a manera de relacionar este análisis con su objetivo general y con su hipótesis que la obra de Guillermo Cifuentes, a través de la idea del desarraigo que expresa con un lenguaje que problematiza sus propios códigos de entendimiento, lo instaura como una figura autoral dentro del video-arte chileno, es decir, como creadora de un lenguaje propio al sacarle partido a este formato en relación a sus capacidades expresivas.

Además se detecta en su obra de video-arte el mérito de hacer converger en ella muchas ramas artísticas, lo cual a pesar de ser algo propio de este formato, lo instauran no como un artista orientado en solo una rama del arte, sino más bien como un artista, un sujeto que en su afán creativo desea experimentar con todos los medios posibles. Como señala Enrique Ramírez:

él decía que él era artista no más, que el tomó la decisión de ser artista y que su trabajo pasa por mucho ramos, por diferentes..eh.. partes, no se cómo decirlo, muchas capas diferentes. Él hacía video-arte pero también era montajista, él hacía instalaciones, podía hacer una lámpara, un día para cuatro personas. Y todo ese conjunto de cosas, que él hacía en su conjunto, lo hacía ser artista, lo que él era.

A pesar de la complejidad que puede ofrecer una obra tan altamente reflexiva y con tantos cruces interdisciplinarios, la particularidad de Guillermo Cifuentes es que, al apelar más a las sensaciones y sentimientos que al orden simbólico de la representación, su obra sea comprensible no solo por gente familiarizada con el lenguaje audiovisual, sino también por gente común y corriente, no relacionada con el ámbito artístico. Su hermana bien recalca respecto a su persona que era un hombre de fácil acceso para conversar, no necesariamente de temas eruditos.

Para finalizar el análisis, se puede decir que esta investigación ha sido fructífera por ofrecer al acceso público la recopilación de las obras de video-arte de Guillermo Cifuentes, las cuales estarán próximamente en la Cineteca de la Universidad de Chile, lugar donde estarán en las mejores condiciones de preservación y a modo de archivo histórico del ámbito artístico político chileno. Como también se planea realizar un documental sobre su obra, acerca de las ideas expuestas en este artículo, es así que las entrevistas realizadas han sido registradas en video. Todo ello en pos de la motivación que guía desde sus principios esta investigación de que su obra no se pierda en el olvido por su desconocimiento. Su hermana comenta:

tenía ese sentido como de la trascendencia, de que la obra trascendía a la persona, que tenía también metida adentro esa cosa como de que la muerte es parte de las probabilidades, de todo el tiempo, entonces había que hacer las mejores cosas lo más rápido posible, no había que perder tiempo... (Antonia Cifuentes)

La perdida de Cifuentes deja atrás una herencia cultural importante porque habla de un 
pasado activo en el presente, que necesita ser recordado: la imagen del pasado como la imagen de uno mismo ¿son acaso uno mismo? ¿Alcanzan a existir en el recuerdo de un otro? ¿Este otro representado soy acaso yo? Estas interrogantes se expresan en repetidos gestos del cuerpo de Cifuentes, en su intento de develar una identidad siempre enmascarada y escondida. Es así que delante de su figura hay un velo que guarda misterios, donde el autor jamás se sale de aquel personaje concentrado en el diálogo con lo que está grabando, con ese afuera que sin su espejo no existe.

\section{Referencias}

Aumont, J. (2005) Estética del cine: espacio fílmico, montaje, narración, lenguaje. Buenos Aires: Paidós.

Benjamin, W. (2004) Elautor como productor. Ciudad de México: Ítaca.

Camitzer, L. (2007) Conceptualism in Latin American Art: Didactics of Liberation. Austin: University of Texas Press.

Cifuentes, G. (2005) “Sitios baldíos”. En: Richard, N.; Oyarzún, P.; Zaldívar, C.; (eds.) Arte y Política. Santiago de Chile: Arcis.

(2007) “Anillo de moebius: cuatro consideraciones sobre el video hoy”. En: La Ferla, J. (comp.) Arte y medios audiovisuales un estado de la situación. Buenos Aires: Aurelia Rivera.

Duarte, P.; Neut, C.; Lasagna, V. (2006) Video-arte en Chile: comunicación expresiva en las sombras. Tesis de Comunicación Social. Universidad Diego Portales.

Elwes, C. (2005) Video Art: A Guided Tour. London: Tauris.

Festival Franco-Chileno de Video-arte (1993). Santiago de Chile: catálogo de la II versión.

Festival Franco-Chileno de Video-arte (2008). Santiago de Chile: catálogo de la VIII versión.

Garáte, R.; Navarrete, J.L. (2002) Teleanálisis: El registro no oficial de una época. Tesis de Comunicación Social. Universidad Diego Portales.

Guasch, A.M. (2006) La crítica dialogada. Murcia: Centro de Documentación y Estudios Avanzados de Arte Contemporáneo.

La Ferla, J. (1991) Video-cuadernos II. Buenos Aires: Servicio Cultural de la Embajada de Francia-Fundación Universidad del Cine.

(1998) Arte audiovisual: tecnologías y discursos. Buenos Aires: Eudeba.

Lara, C.; Machuca, G.; Rojas, S. (2005) Chile - Arte extremo: nuevas tendencias en el cambio de siglo. Santiago: CNCA.

Marchán Fiz, S. (1986) Del arte objetual al arte de concepto: epílogo sobre la sensibilidad postmoderna. Madrid: Akal.

Martin, S. (2006) Video-Art. Köln: Taschen.

Neustadt, R. (2001) Cada día: la creación de un arte social. Santiago de Chile: Cuarto Propio.

Olhagaray, N. (2002) Delvideo-arte alnet-art. Santiago de Chile: LOM.

- (2007) “Homenaje a Guillermo Cifuentes”. Catálogo de la VIII Bienal de Video y Nuevos 
Medios. Santiago de Chile.

Ossa, C. (2005) “Inmediatez y frontera”. En: Richard, N.; Oyarzún, P.; Zaldívar, C.; (eds.) Arte y Politica. Santiago de Chile: Arcis.

Richard, N. (1994) La insubordinación de los signos. Santiago de Chile: Cuarto Propio.

Sánchez-Biosca, V. (2004) Cine y vanguardias artísticas. Barcelona: Paidós.

Stam, R. (2001) Teorías delcine. Ciudad de México: Paidós. 